\title{
Small is big! The role of 'small' audits for studying the audit market
}

\author{
Nieves Carrera \\ IE University, IE Business School, Madrid, Spain \\ Email: nieves.carrera@ie.edu \\ Marco Trombetta \\ IE University, IE Business School, Madrid, Spain \\ Email: marco.trombetta@ie.edu
}

\section{INTRODUCTION}

Studying history will not be complete if the focus lies only on the most powerful and rich segments of society. In order to fully understand historical facts, it is crucial to gather data on and analyze ordinary people, which constitute the vast majority of the population. Something similar is true for studying the audit services market. If we only focus on the so-called Big $\mathrm{N}$ audit firms and their large, listed, clients, we do not have an in-depth understanding of the market. By 2014, in the 28 countries of the European Union (EU), 92.98\% of the enterprises were microenterprises, i.e. they had less than 10 employees. If we restrict our attention to the 'accounting, bookkeeping, auditing, and tax services' market, the percentage grows up to $95.63 \%$ (Eurostat, 2017). In other jurisdictions, the percentages are similar or even higher. It is a fact, therefore, that the vast majority of audit firms and their current and potential clients are small and medium-sized enterprises (SMEs).

Despite the importance of SMEs for the audit market, only quite recently the academic literature has given the attention they deserve. Lack of accessible and reliable data is likely to be one of the reasons why many studies in the past have neglected this segment of the market and have focused on large audit firms. In this Editorial we focus on the insights generated by recent literature examining SMEs in the audit market, both from the supply and demand side. We highlight how this strand of the literature has improved our understanding of how the audit services market works and how it provides many opportunities for further research.

\section{THE SUPPLY SIDE: IS THE AUDIT MARKET COMPETITIVE?}

The high level of concentration and the possible lack of competition in the audit market have been a matter of concern to regulators for a long time. In his seminal paper, Simunic (1980, p. 161) started with the following phrase:

The question of the existence of competition among auditors
has been the subject of considerable discussion in recent years.
More specifically, the "Big Eight" firms as a group have been
accused of monopolizing the market for audit.

More than 30 years later, Numan and Willekens (2012, p. 451) opened the 'Motivation and Contribution' section of their paper stating that:

The audit market is characterized by a high level of concentration, regulated demand for audits by listed firms, and high barriers to entry due to reputation effects and the need for specialized knowledge. Regulators in different countries often express concerns about whether the degree of competition in the audit market is sufficient.

At a first glance, we could have the impression that our understanding of the audit market's competitive dynamics has not improved much within these three decades, if scholars are still tackling the same core question: is the audit services market sufficiently competitive in order to guarantee an adequate level of quality at an acceptable price? Perhaps, this pessimistic view is not justified. During thirty years, the academic literature has accumulated a great deal of empirical evidence about the audit market's competitive dynamics. However, such empirical evidence 
have not been able to establish any clear regularity about the relationship between market concentration and audit fees and audit quality - for references on audit fees, see Eshleman and Lawson (2017); for references on audit quality, see DeFond and Zhang (2014).

According to Simunic (1980), prior studies generally assume that Big $\mathrm{N}$ and non-Big $\mathrm{N}$ audit firms operate in two separate segments of the market that very rarely intersect. However, recent literature puts this assumption into question and analyzes the interactions between these two segments and their implications for audit fees and audit quality (Bills \& Stephens, 2016; Keune, Mayhew, \& Schmidt, 2016).

From a theoretical viewpoint, this recent strand of the literature refers to the notion of 'spatial competition' (Hotelling, 1929; Tirole, 1988). In a perfectly competitive market, price competition should lead to a unique equilibrium price equal to marginal cost. However, in real life, we observe different equilibrium prices in the same market that do not necessarily equate marginal cost. This outcome may be attributed to product differentiation. Before competing in prices, firms choose where to locate in the product space. The further they locate in the product space at the first stage, the weaker is price competition at the second stage.

Somehow surprisingly, it is not until recently that this theoretical framework has been applied to studying competition in the audit market. Chan (1999) adapts the classic horizontal spatial competition model to the audit services market. Two stylized features of this market are inserted in the model: industry specialization and setup costs, i.e. the fact that the first audit of a new client is more costly than subsequent audits, because of the initial investments required to become familiar with the client's accounting system. In this setting, three major effects should be taken into account by an audit firm in choosing its optimal specialization strategy. The first is the 'market share' effect. In order to gain market share, audit firms need to reduce diversification, while choosing industry specialization. By doing this, they become more attractive for a larger share of potential clients. The second is the 'strategic' effect. In order to relax price competition, firms need to differentiate as much as possible and choose an extreme level of industry specialization. The third is the 'cost reduction' effect. The closer the audit firm gets to a client in terms of industry specialization, the lower is its cost to perform an audit. If only the first two effects are considered, then the 'strategic' effect dominates and, in equilibrium, firms differentiate as much as possible and locate as far as possible from each other. However, if the 'cost reduction' effect is introduced, the 'market share' effect dominates and firms locate fairly close to each other in terms of specialization. Hence, according to this model, we expect audit firms to offer fairly similar products and have fairly similar market shares. Chan (1999) claims that this model provides a good description of competition between Big $\mathrm{N}$ firms and that such a competition could be quite fierce, despite the concentration.

Numan and Willekens (2012) were the first authors applying this framework to an empirical study of real audit markets. As a proxy for the 'cost reduction' effect, Numan and Willekens (2012) use the percentage of total revenue generated by an audit firm in a specific sector, i.e. the degree of industry specialization in terms of revenue. The higher the level of general industry specialization, the higher audit fees are expected to be in equilibrium. To verify whether the 'market share' effect or the 'strategic' effect dominates, the authors use the difference between the market shares of the incumbent auditor and the closest competitor in the same market. They adopt Metropolitan Statistical Areas (MSAs) in the United States of America (USA) as separate local markets, in which their hypotheses are tested and both the 'market share' effect and the 'strategic' effect are observed. Audit fees are increasing in both general industry specialization and market shares distance from the closest competitor in the same industry, showing predominance of the 'strategic' effect.

Numan and Willekens (2012) focus on Big N firms and follow Simunic (1980) and Chan (1999) in assuming that competition between Big $\mathrm{N}$ and non-Big $\mathrm{N}$ audit firms takes place in two separate markets, which do not influence each other. Both Bills and Stephens (2016) and Keune, Mayhew and Schmidt (2016) challenge this critical assumption while keeping spatial competition as the underlying theoretical framework. When we move away from the audit market for multinational listed companies and focus on local markets for audits of private clients, casual observation shows that, in these local markets, the leading auditor is not necessarily a Big N firm. Again, it is quite surprising that this fact has triggered rigorous empirical analysis only very recently.

Keune, Mayhew and Schmidt (2016) choose for their empirical analysis the same markets as Numan and Willekens (2012), i.e. MSAs in the USA. Using local rankings of auditors, the authors show that in markets where the leader is a non-Big Four firm, the overall level of audit fees is lower. Bills and Stephens (2016) also address MSAs in the USA. They focus on the absolute difference in market shares between 2 competing audit firms and find that the distance between Big Four firms and the closest 
non-Big Four firm is more important in determining the general level of audit fees than the distance between Big Four competitors only. Moreover, the closer a non-Big Four firm gets to its closest Big Four competitor, the lower the level of audit fees. Both studies show that the role played by non-Big Four firms is crucial in determining the overall level of competitiveness in local markets for audit services and the level of audit fees in these markets.

So, let us go back to the original question: is the audit services market sufficiently competitive? Now, we can say that this question cannot be properly addressed by focusing exclusively on an audit market for listed clients dominated by the Big Four audit firms (the 'large' audit market). We need to extend our analysis to local markets where private businesses of various sizes, including SMEs, demand audit services. In these markets, Big Four and non-Big Four firms do compete and interact (the 'small' audit market). Empirical evidence gathered recently show that, at this extended level of analysis, the audit market competitiveness is high and the market dynamics is complex, putting into question the need for regulatory intervention aimed at increasing competition.

\section{THE DEMAND SIDE: DO PRIVATE SMEs DEMAND AUDIT?}

Listed companies are required to have their annual report audited. Consequently, in the 'large' audit market dominated by the Big Four, an economically significant demand is guaranteed by regulatory requirements. When we move to local, small, audit markets, we need to take into account the demand for audits of private SMEs - which are not always required to undergo an audit. Vanstraelen and Schelleman (2017) provide a comprehensive literature review of auditing in private firms.

The policies for compulsory audits vary significantly from country to country (Minis \& Shroff, 2017). In the USA and Canada, private companies are generally not required to have an audit of financial statements, regardless of their size. Under the EU regulation, audit exemptions for private companies are based on firm size proxied by number of employees, assets, and annual turnover. In many jurisdictions, the decision to audit their financial statements is voluntary. Why do they consider that the benefits of an external audit overcome its costs? What are the benefits of voluntary audits? A relatively small, but increasing number of studies have investigated these issues (e.g. Dedman, Kausar, \& Lennox, 2014; Minnis \& Shroff, 2017).

Several studies have examined the influence of private SMEs' agency costs on the demand of voluntary audits (Hope, Langli, \& Thomas, 2012). Typically, SMEs show less agency conflicts related to the separation of ownership and management than public, large, firms. However, we may expect more prominent agency costs associated to conflicts between different owners. Overall, outcomes suggest that firms are more likely to undergo voluntary audits if they have greater agency costs (Carey, Simnett, \& Tanewski, 2000; Collis, 2010; Dedman, Kausar, \& Lennox, 2014). Furthermore, the level of shareholder-debtholder agency costs and contractual constraints imposed by creditors on the firm seem to be a key driver for the demand of voluntary audits in SMEs (e.g. Abdel-Khalik, 1993; Carey, Simnett, \& Tanewski, 2000; Seow, 2001; Senkow, Rennie, Rennie, \& Wong, 2001; Corten, Steijvers, \& Lybaert, 2015). Other business characteristics, such as size, age, incorporation status and business complexity, have also been identified as drivers of voluntary audits' demand (e.g. Collis, Jarvis, \& Skerratt, 2004; Allee \& Yohn, 2009; Cassar \& Ittner, 2009; Minnis, 2011; Collis, 2010; Dedman, Kausar, \& Lennox, 2014).

Managers of SMEs may use an external audit as an internal control mechanism when organizational complexity increases - e.g. to compensate for the hierarchical loss of control over employees when a company increases in size (Abdel-Khalik, 1993; Senkow et al., 2001; Seow, 2001). SMEs may also demand voluntary audits expecting to get from auditors skills and resources not available within them. Empirical evidence suggest that SMEs value the business advice provided by external auditors in areas such as taxation and accounting (e.g. Niemi, Kinnunen, Ojala, \& Troberg, 2012; Bianchi, in press; Collin, Ahlberg, Berg, Broberg, \& Karlsson, 2017). Furthermore, SMEs see that auditors may play a role in supporting management decisions, as well as help improving operational efficiency and effectiveness (Collis, 2012; Ojala, Collis, Kinnunen, Niemi, \& Troberg, 2016).

Finally, recent studies have examined the influence of institutions and macroeconomic factors on the voluntary demand of audits. Voluntary audits may be seen as a substitute for weak institutional environments (Francis, Khurana, Martin, \& Pereira, 2011). Moreover, within periods of economic growth, there is a decrease in the use of audited financial statements by banks, leading to lower demand for audits (Lisowsky, Minnis, \& Sutherland, 2017).

To sum up, recent literature indicates that voluntary audits demanded by SMEs may be a response to their agency conflicts; they could also be a powerful management 
tool for solving internal issues and/or to compensate for the lack of strong institutional protection. What about the consequences of voluntary audits for SMEs?

So far, prior research examining the potential benefits derived from voluntary audits has been restricted to its impact on debt contracting and on financial information quality (Kim, Simunic, Stein, \& Yi, 2011; Minnis, 2011; Clatworthy \& Peel, 2013; Kausar, Shroff, \& White, 2016). Voluntary audits facilitate debt contracting for two reasons. First, they may alleviate information uncertainty faced by lenders; second, the assurance provided by an audit may reduce debt monitoring and negotiation costs (Blackwell, Noland, \& Winters, 1998; Kim et al., 2011). Empirical research from Korea, the United Kingdom (UK) and the USA supports these arguments (Blackwell, Noland, \& Winters, 1998; Minnis, 2011; Kim et al., 2011; Lennox \& Pittman, 2011; Dedman \& Kausar, 2012; Kausar, Shroff, $\&$ White, 2016). Hope, Thomas and Vyas (2011), using a 68-country sample, find similar results.
The second potential benefit of voluntary audits is higher financial reporting quality. It is argued that an external audit improves the quality and credibility of the accounts, thereby the informative value of financial statements for third parties. While this argument is generally taken for granted, there is limited empirical evidence of the beneficial effect of voluntary audits on accounting quality, where Dedman and Kausar (2012) and Clatworthy and Peel (2013) constitute two major exceptions. Dedman and Kausar (2012) show that voluntary audits are associated with less conservative financial reporting. Clatworthy and Peel (2013) found out that audited financial statements of private firms are nearly half as likely as unaudited accounts to contain accounting errors.

In sum, prior studies provide empirical evidence of a demand for voluntary audits and the positive consequences that purchasing these voluntary audits brings for SMEs, both in terms of debt contracting and accounting quality.

\section{SUGGESTIONS FOR FURTHER RESEARCH}

As highlighted by Cassar (2011), the setting of private firms offers many opportunities to understand key accounting issues. The previous sections summarize what we have learnt from the existing literature. Where can we go from here?

Further research exploring the heterogeneity of regulations and environments where private SMEs operate is needed. Mandatory audits constitute a policy used by governments to regulate financial reporting quality. There is a rich variety of regulatory regimes regarding mandatory audits for private SMEs. This empirical variation can provide fruitful insights into the role of auditing in society. Prior research has examined companies' reaction to changes in the regulatory regime, to better understand the benefits of voluntary audits (e.g. Lennox \& Pittman, 2011; Kausar, Shroff, \& White, 2016). Further research on threshold changes, exempting certain companies from mandatory audits, may contribute to current debate on the costs and benefits of auditing SMEs. Such investigation may also assess the validity of thresholds based on metrics such as size, revenues, and employees for audit exemptions. Minnis and Shroff (2017) provide interesting ideas for further studies. For instance, these authors claim there is a need for research providing evidence about the extent to which privately contracted auditors act as compliance monitors in various countries. This is particularly relevant in the case of developing countries, given the role of SMEs and the weak institutional environments that typically characterize these settings.
As prior research suggests (e.g. Minnis, 2011), client firm characteristics have a significant influence on audit costs and benefits. A promising area for further research consists in exploring the heterogeneity within private SMEs, as an attempt to better understand the dynamics of the audit demand. For instance, studies may examine potential costs and benefits of voluntary audits for family firms, start-ups, or fast-growing companies.

More research is also needed to better understand the relationship between SMEs and small and medium audit practices and their 'key' individuals (CEOs/owners, managers, and audit partners). For instance, it may be worth exploring the role of individual traits (human capital, social capital, age, or experience) in the audit process - from engagement to audit report issuance. Prior research has shown that, in the case of mandatory audits, individual attributes influence auditors' compensation, both in large and small-sized audit firms (e.g. Knechel, Niemi, Zerni, 2013; Bianchi, Carrera, \& Trombetta, 2017). As far as we know, no studies have simultaneously considered the individual traits of business owners and auditors. Questions remain regarding the extent to which individual skills may influence a firm's financial reporting quality. Exploring the role of individual attributes of both owners/managers (e.g. Allee \& Yohn, 2009) and auditor in the audit firm selection process may provide interesting insights into the factors for success in the 'small audit market.' 
According to DeFond and Zhang (2014, p. 304), the audit process "is a black box to archival auditing researchers, primarily due to data limitations." Further research on audit processes with a specific focus on SMEs may provide insights into how auditors deal with heterogeneity in critical input quality during the audit process, i.e. preaudit financial statements. Furthermore, there is virtually no research exploring fraud risk assessment and audit procedures for detecting fraud. Using proprietary data from SMEs could provide interesting insights into this critical stage of the audit process. Furthermore, auditors in this setting provide much more than assurance of financial statements. Studies such as Niemi et al. (2012), Ojala et al. (2016), and Collin et al. (2017) bring insights into the added value provided by external auditors in areas such as taxation, accounting, and decision making. Questions remain regarding the extent to which the implicit provision of these additional services in audit engagement may affect auditor independence (Vanstraelen \& Schelleman, 2017). Further research may also explore the potential impact of auditors on performance metrics, as well as the social impact of audits on SMEs.

There is also a need for revisiting the concept of audit quality and its relationship with financial reporting quality (Gaynor, Kelton, Mercer, \& Yohn, 2016) in the specific context of SMEs. Further studies should consider alternative metrics for audit quality and accounting quality, better fitted to the context of private SMEs. These metrics may take into account, e.g. how auditors influence the financial reporting process, including the potential effect of auditors' individual traits, as previously noticed. Another factor to consider is the stakeholders' perception of 'accounting quality' (e.g. creditors and suppliers) in the case of SMEs, which may differ significantly from the perception of shareholders and stakeholders from large, public, companies. More research is also needed in the quality control area, as little is known about the effects of regulatory intervention on audit quality provided by small and medium practices in the 'small' audit market.

It is quite surprising how little the audit literature has benefited from the theoretical and empirical industrial organization literature, in order to address competition in the audit market. Even in a 'mature' textbook, such as Tirole (1988), we can find much more competition models with product differentiation other than the classic horizontal 'spatial competition' model used by recent audit studies. For instance, vertical product differentiation models and minimum quality standards may be useful in describing competitive interaction between firms of various sizes offering different levels of audit quality under different quality regulation regimes - see Trombetta (2003) for an example of international regulation of audit quality and auditors' liability. Using distance between market shares in the same industry as a proxy for spatial location has been inspired by empirical analysis applied to the banking sector. Studies examining other sectors, where the competition degree constitutes a matter of concern (e.g. phone and data services or airlines) could stimulate alternative approaches that may lead to highlight specific features of the audit market dynamics neglected by prior research.

Interestingly, the recent literature has shown how important local markets are. This conclusion calls for further studies from smaller countries and/or specific regions within a certain country. This is a big opportunity for non-USA based research projects to play a leading role in the academic and policy making debate. Moreover, most of the suggestions for further research above require access to proprietary data and/or information gathered through interviews, questionnaires, and surveys. Proprietary data and working papers may help getting closer to the 'reality' of the audit process. Interviews may allow researchers to gain critical information about the interaction between business owners, managers, and auditors, as well as about the accounting system and the audit process (e.g. Cohen, Krishnamoorthy, \& Wright, 2017). Surveys and questionnaires may be used to collect information on individual traits. While behavioral research and field studies have a comparative advantage in this regard, archival researchers should use "creative settings and research designs to open up the 'black box"' (DeFond \& Zhang, 2014, p. 304). The opportunity is here! 


\section{REFERENCES}

Abdel-Khalik, A. R. (1993). Why do private companies demand auditing? A case for organizational loss of control. Journal of Accounting, Auditing \& Finance, 8(1), 31-52.

Allee, K. D., \& Yohn, T. L. (2009). The demand for financial statements in an unregulated environment: an examination of the production and use of financial statements by privately held small businesses. The Accounting Review, 84, 1-25.

Bianchi, P. A. (in press). Auditors' joint engagements and audit quality: evidence from Italian private companies. Contemporary Accounting Research.

Bianchi, P. A., Carrera, N., \& Trombetta, M. (2017). The determinants of individual auditor compensation from the small audit firm market (Working Paper). Madrid: IE Business School.

Bills, K. L., \& Stephens, N. M. (2016). Spatial competition at the intersection of the large and small audit firm markets. Auditing: A Journal of Practice \& Theory, 35(1), 23-45.

Blackwell, D., Noland, T., \& Winters, D. (1998). The value of auditor assurance: evidence from loan pricing. Journal of Accounting Research, 36, 57-70.

Carey, P., Simnett, R. \& Tanewski, G. (2000). Voluntary demand for internal and external auditing by family businesses. Auditing: A Journal of Practice \& Theory, 19(Supplement), 37-51.

Cassar, G. (2011). Discussion of the value of financial statement verification in debt financing: evidence from private U.S. firms. Journal of Accounting Research, 49, 507-528.

Cassar, G., \& Ittner, C. D. (2009). Initial retention of external accountants in start-up ventures. European Accounting Review, $18,313-340$

Chan, D. (1999). 'Low-balling' and efficiency in a two-period specialization model of auditing competition. Contemporary Accounting Research, 16(4), 609-642.

Clatworthy, M. A., \& Peel, M. J. (2013). The impact of voluntary audit and governance characteristics on accounting errors in private companies. Journal of Accounting and Public Policy, 32, $1-25$.

Cohen, J., Krishnamoorthy, G., \& Wright, A. (2017). Enterprise risk management and the financial reporting process: the experiences of audit committee members, CFOs, and external auditors. Contemporary Accounting Research, 34(2), 11781209.

Collin, S.-V. Y., Ahlberg, J., Berg, K., Broberg, P., \& Karlsson, A. (2017). The auditor as consigliere in family firm. Journal of Family Business Management, 7(1), 2-20.

Collis, J. (2010). Audit exemption and the demand for voluntary audit: a comparative study of the UK and Denmark. International Journal of Auditing, 14, 211-231.

Collis, J. (2012). Determinants of voluntary audit and voluntary full accounts in micro- and non-micro small companies in the UK. Accounting and Business Research, 42(4), 441-468.

Collis, J., Jarvis, R., \& Skerratt, L. (2004). The demand for the audit in small companies in the UK. Accounting \& Business Research, 34(2), 87-100.
Corten, M., Steijvers, T., \& Lybaert, N. (2015). The demand for auditor services in wholly family owned private firms: the moderating role of generation. Accounting and Business Research, 45(1), 1-26.

Dedman, E., \& Kausar, A. (2012). The impact of voluntary audit on credit ratings: evidence from UK private firms. Accounting and Business Research, 42(4), 397-418.

Dedman, E., Kausar, A., \& Lennox, C. (2014). The demand for audit in private firms: recent large-sample evidence from the UK. European Accounting Review, 23(1), 1-23.

DeFond, M., \& Zhang, J. (2014). A review of archival auditing research. Journal of Accounting and Economics, 58, 275-326.

Eshleman, J. D., \& Lawson, B. P. (2017). Audit market structure and audit pricing. Accounting Horizons, 31(1), 57-81.

Eurostat. (2017). Your key to European statistics. Retrieved from http://ec.europa.eu/eurostat/web/main/home

Francis, J. R., Khurana, I. K., Martin, X., \& Pereira, R. (2011). The relative importance of firm incentives versus country factors in the demand for assurance services by private entities. Contemporary Accounting Research, 28(2), 487-516.

Gaynor, L. M., Kelton, A. S., Mercer, M., \& Yohn, T. L. (2016). Understanding the relation between financial reporting quality and audit quality. Auditing: A Journal of Practice \& Theory, 35(4), 1-22.

Hope, O.-K., Langli, J., \& Thomas, W. (2012). Agency conflicts and auditing in private firms. Accounting, Organizations and Society, 37(7), 500-517.

Hope, O.-K., Thomas, W. B., \& Vyas, D. (2011). Financial credibility, ownership, and financing constraints in private firms. Journal of International Business Studies, 42, 935-957.

Hotelling, H. (1929). Stability in competition. The Economic Journal, 39(153), 41-57.

Kausar, A., Shroff, N., \& White, H. (2016). Real effects of audit choice. Journal of Accounting and Economics, 61, 157-181.

Keune, M. B., Mayhew, B. W., \& Schmidt, J. J. (2016). Non-Big 4 local market leadership and its effect on competition. The Accounting Review, 91(3), 767-792.

Kim, J-B., Simunic, D., Stein, M., \& Yi, C. H. (2011). Voluntary audits and the cost of debt capital for privately held firms: Korean evidence. Contemporary Accounting Research, 28, 585-615.

Knechel, R. W., Niemi, L., \& Zerni, M. (2013). Empirical evidence on the implicit determinants of compensation in Big 4 audit partnerships. Journal of Accounting Research, 51(2), 349-387.

Lennox, C., \& Pittman, J. (2011). Voluntary audits versus mandatory audits. The Accounting Review, 86, 1655-1678.

Lisowsky, P., Minnis, M., \& Sutherland, A. (2017). Economic growth and financial statement verification. Journal of Accounting Research, 55(4), 745-794.

Minnis, M. (2011). The value of verification in debt financing: evidence from private U.S. firms. Journal of Accounting Research, 49, 457-506.

Minnis, M., \& Shroff, N. (2017). Why regulate private firm 
disclosure and auditing? Accounting and Business Research, 47(5), 473-502.

Niemi, L., Kinnunen, J., Ojala, H., \& Troberg, P. (2012). Drivers of voluntary audit in Finland: to be or not to be audited? Accounting and Business Research, 42(2), 169-196.

Numan, W., \& Willekens, M. (2012). An empirical test of spatial competition in the audit market. Journal of Accounting and Economics, 53, 450-465.

Ojala, H., Collis, J., Kinnunen, J., Niemi, L., \& Troberg, P. (2016). The demand for voluntary audit in micro-companies: evidence from Finland. International Journal of Auditing, 20(3), 267-277.

Senkow, D. W., Rennie, M. D., Rennie, R. D., \& Wong, J. W. (2001) The audit retention decision in the face of deregulation: evidence from large private Canadian corporations. Auditing:
A Journal of Practice \& Theory, 20(2), 101-113.

Seow, J. L. (2001). The demand for the UK small company audit: an agency perspective. International Small Business Journal, 19, 61-79.

Simunic, D. (1980). The pricing of audit services: theory and evidence. Journal of Accounting Research, 18(1), 161-190.

Tirole, J. (1988). The theory of industrial organization. Cambridge, MA: The MIT Press.

Trombetta, M. (2003). International regulation of audit quality: full harmonization or mutual recognition? An economic approach. European Accounting Review, 12(1), 3-27.

Vanstraelen, A., \& Schelleman, C. (2017). Auditing private companies: what do we know? Accounting and Business Research, 47(5), 565-584. 